\title{
Effect of different doses of nitrogen on growth and yield parameters of radish (raphanus sativus I.) in mid-hills of Nepal
}

\begin{abstract}
The optimization of nitrogen application for root crops like radish is important for attaining the optimum growth and yield. Therefore the present study was carried out at Horticulture Research Farm of IAAS, Tribhuwan University to evaluate the effect of six different levels $(0 \mathrm{~kg}, 30 \mathrm{~kg}, 60 \mathrm{~kg}, 90 \mathrm{~kg}, 120 \mathrm{~kg}$ and $120 \mathrm{~kg} / \mathrm{ha})$ of Nitrogen on growth and yield parameters of radish. The results showed that the higher level of nitrogen has no any significant effect on some parameters such as number of leaves at $40 \mathrm{DAS}$, leaf length, leaf breadth and root diameter however increased doses of nitrogen showed highly significant relationship with the number of leaves at 50DAS, root length at 40DAS, root weight at $40 \& 50$ DAS. The maximum number of leaves $(20.87,15.58,14.08)$, root length at 40DAS $(13.37,12.32,11.50 \mathrm{~cm})$, root weight at 40DAS $(46.63,42.00,35.50 \mathrm{~g})$ root weight at 50DAS $(307.50,302.50,234.50 \mathrm{~g})$ were recorded when $\mathrm{N}$ was applied @ 90,120 and $150 \mathrm{~kg}$ per hectare respectively.
\end{abstract}

Keywords: growth parameters, nitrogen, radish
Volume 2 Issue 6 - 2018

\author{
Abhisek Shrestha,' Bharti Thapa \\ IInstitute of Agriculture and Animal science, Post graduate, \\ Nepal \\ ${ }^{2}$ Institute of Agriculture and Animal Science (IAAS), Lamjung
}

Correspondence: Abhisek Shrestha, Institute of Agriculture and Animal science, Post graduate, Nepal,

Email shrestha.avil425@gmail.com

Received: May 23, 2018 | Published: December 31, 2018

\section{Introduction}

Radish (Raphanus sativus L.) belongs to Cruciferae family and is one of the most popular root vegetable crops that can successfully grown throughout the year in the hills of Nepal. The popularity of radish among the large number of farmers is due to its rapidly growing habit, short growing period, ease in cultivation and wider climatic adaptation. ${ }^{1}$ It is mainly cultivated for its fleshy root and tender leaves which can be eaten raw as salad or cooked as a vegetable. It is an excellent source of carbohydrates, proteins and vitamin A \& C. It has cooling effect, prevents constipation, increase appetite and is recommended to the patients suffering from piles, liver trouble, enlarged spleen and jaundice. ${ }^{2}$ In Nepal radish is grown on an area of 18190 ha with the total production of 272152 metric tones. The average productivity of radish is $15.0 \mathrm{mt} / \mathrm{ha}^{3}$ which is low as compared with the other agricultural countries. Mino Early, White Neck, Forty Days and Pyuthane Red are released varieties of radish with greater potential yield in Nepal, however its yield at the farmers field is not satisfactory. The main reasons behind this might be the inappropriate production technology and inefficient nutrient management.

There are many factors responsible for decline in its quality and yield. Apart from other factors, nutrients play vital role in the production of certain crops and its application is one of the quickest and easiest way in increasing yield per unit area. Among the major essential nutrients required by the plants for their growth, development and yield the role of nitrogen is inevitable ${ }^{2}$ as it is necessary component of metabolically active compound like protein, nucleic acids, chlorophyll and certain important enzymes. ${ }^{4,5}$

Many workers reported that the application of adequate level of nitrogen positively affect the growth character such as plant height, number of leaves, leaf length, leaf breadth, leaf weight and yield parameters like total biomass, root length, root diameter and root yield. Jilani et al. ${ }^{2}$ observed the significant increase in number of leaves $(18.70)$, leaf length $(33.33 \mathrm{~cm})$ weight of leaves $(160.67 \mathrm{~g})$, root length $(23.77 \mathrm{~cm})$, root diameter $(4.43 \mathrm{~cm})$, root weight $(139.28 \mathrm{~g})$ and yield(99.88t/ha) under application of $200 \mathrm{~kg} / \mathrm{ha} \mathrm{N}$. Baloch et al. ${ }^{4}$ reported that an increase in nitrogen levels from 100 to $150 \mathrm{~kg} / \mathrm{ha}$ positively affected all the growth and yield parameters of raddish. Patil et al. ${ }^{6}$ found that application of $150 \mathrm{kgN} / \mathrm{ha}$ along with $75 \mathrm{kgP} / \mathrm{ha}$ in soil and foliage significantly increased the number of leaves, total fresh weight per plant, total dry matter accumulation per plant and the diameter of root. Pervez et al. ${ }^{5}$ reported that application of $200 \mathrm{kgN} / \mathrm{ha}$ significantly affect on the number of leaves $(16.3)$, root length $(33 \mathrm{~cm})$, plant height $(83.0 \mathrm{~cm})$, root diameter $(4.5 \mathrm{~cm})$, total biomass and root yield. The present study is thus carried out to find out the optimum doses of nitrogen for attaining the optimum growth and yield of radish.

\section{Materials and methods}

This study was carried out at Horticultural Research Farm of Institute of Agriculture and animal science (IAAS), Tribhuwan University during the winter season of 2015. The experiment was laid out in single factor Randomized Complete Block Design (RCBD) with six treatments replicated four times using a plot size of $1.5 \times 1.5$ $\mathrm{m}^{2}$. The blocks were designated on the basis of homogeneity of the experimental field. The seeds of variety forty days were sown on the lines with row to row distance of $25 \mathrm{~cm}$ and plant to plant distance of $10 \mathrm{~cm}$. Well decomposed Farm Yard Manure (FYM) was applied as a source of organic fertilizer. Six nitrogen levels $(0.30,60,90,120$ and $150 \mathrm{~kg} \mathrm{~N} / \mathrm{ha}$ ) were applied. Urea was used as a source of nitrogen fertilizer and was applied in single doses at the time of sowing. Potash was also applied as constant doses of $50 \mathrm{~kg} / \mathrm{ha}$ at the time of sowing. All required cultural practices like irrigation, hoeing, weeding, pest and disease control, etc. were given uniformly whenever necessary. First weeding was done at 14 DAS and the second weeding was done at 30 DAS. The experimental plot was regularly observed and three plants were randomly selected from each plot to collect the required information. Data were recorded for number of leaves, leaf length $(\mathrm{cm})$, breadth of leaves $(\mathrm{cm})$, root diameter $(\mathrm{cm})$, root weight $(\mathrm{g})$ at 40 \& 50 DAS respectively while root length $(\mathrm{cm})$ was recorded only at 40 DAS. The data were entered using MS- excel and was 
analyzed statistically using SPSS 16.0 computer software at 5\% level of significance. The data (Table 1) regarding number of leaves at 40DAS, leaf length at 40DAS and 50 DAS, leaf breadth at 40 DAS and root diameter at 50 DAS revealed non- significant over any of the treatment of nitrogen level.

\section{Number of leaves at 50DAS}

The data regarding number of leaves at 50DAS showed significant effect with nitrogen application which increased proportionally with an increase in nitrogen fertilizer level upto certain level. N@150kg showed highly significant effect on number of leaves at 50DAS with
20.87 leaves (Table 2). However under control treatment the number of leaves was least statistically at par with $30 \mathrm{kgN}$. The effect of application of $30 \mathrm{~kg} \mathrm{~N}$ was at par with that at $60 \mathrm{~kg} \mathrm{~N}$ and similar result was obtained among $60 \& 90 \mathrm{~kg} \mathrm{~N}$ and $90 \& 120 \mathrm{~kg} \mathrm{~N}$. Similar results were obtained by Jilani et al, ${ }^{2}$ Patil et al. ${ }^{6}$ and Baloch et al ${ }^{4}$ Increase in leaves production with higher level of $\mathrm{N}$ may be attributed to increased uptake of $\mathrm{N}$ which being the constituent of protein and component of protoplasm that might favorably affect the chlorophyll content of the leaves resulting in increased synthesis of carbohydrates which are further utilized in building up of new cells.

Table I Effect of nitrogen level on number of leaves, leaf length \& leaf breadth at 40DAS and leaf length \& root diameter at 50DAS

\begin{tabular}{llllll}
\hline Nitrogen level (kg/ha) & $\begin{array}{l}\text { No. of } \\
\text { Leaves } \\
\text { 40 DAS }\end{array}$ & $\begin{array}{l}\text { Leaf } \\
\text { length(cm) } \\
\text { 40 DAS }\end{array}$ & $\begin{array}{l}\text { Leaf } \\
\text { length(cm) } \\
\text { 50DAS }\end{array}$ & $\begin{array}{l}\text { Leaf } \\
\text { breadth(cm) } \\
\text { 40 DAS }\end{array}$ & $\begin{array}{c}\text { Root } \\
\text { diameter(cm) } \\
\text { 50 DAS }\end{array}$ \\
\hline 0 & 9.66 & 12.19 & 18.65 & 6.51 & 2.49 \\
30 & 9.91 & 14.53 & 19.55 & 6.63 & 2.88 \\
60 & 10.66 & 14.8 & 20.21 & 7.44 & 2.94 \\
90 & 10.66 & 14.8 & 22.04 & 7.54 & 3.23 \\
120 & 11.08 & 15.63 & 22.57 & 7.8 & 3.31 \\
150 & 12.33 & 15.63 & 23.4 & 8.47 & 3.44 \\
Significance & NS & NS & NS & NS & NS
\end{tabular}

NS, non significant

Table 2 Effect of nitrogen level on root length \& root weight at 40DAS and number of leaves \& root weight at 50 DAS

\begin{tabular}{lllll}
\hline $\begin{array}{l}\text { Nitrogen } \\
\text { level( kg/ha) }\end{array}$ & $\begin{array}{l}\text { No. of Leaves } \\
\text { 50DAS }\end{array}$ & $\begin{array}{l}\text { Root length(cm) } \\
\text { 40 DAS }\end{array}$ & $\begin{array}{l}\text { Root weight(g) } \\
\text { 40DAS }\end{array}$ & $\begin{array}{c}\text { Root weight(g) } \\
\text { 50 DAS }\end{array}$ \\
\hline 0 & $10.58 \mathrm{e}$ & $8.80 \mathrm{~d}$ & $28.50 \mathrm{e}$ & $161.25 \mathrm{~d}$ \\
30 & $11.66 \mathrm{de}$ & $9.20 \mathrm{~cd}$ & $29.75 \mathrm{de}$ & $195.75 \mathrm{c}$ \\
60 & $12.91 \mathrm{~cd}$ & $10.93 \mathrm{bcd}$ & $31.50 \mathrm{~d}$ & $200.25 \mathrm{c}$ \\
90 & $14.08 \mathrm{bc}$ & $11.50 \mathrm{abc}$ & $35.50 \mathrm{c}$ & $234.50 \mathrm{~b}$ \\
120 & $15.58 \mathrm{~b}$ & $12.32 \mathrm{ab}$ & $42.00 \mathrm{~b}$ & $302.50 \mathrm{a}$ \\
150 & $20.87 \mathrm{a}$ & $13.37 \mathrm{a}$ & $46.63 \mathrm{a}$ & $307.50 \mathrm{a}$ \\
Significance & $* *$ & $* *$ & $* *$ & $* *$ \\
\hline
\end{tabular}

**highly significant

\section{Root length at 40 DAS}

Application of $150 \mathrm{kgN}$ shows significantly longer roots $(13.37 \mathrm{~cm})$ which was statistically at par with $120 \& 90 \mathrm{kgN}$ with average root length of 12.32 and $12.50 \mathrm{~cm}$ respectively. However under control treatment the length of root was significantly shorter as compared with the other and was at par with $30 \mathrm{~kg} \mathrm{~N}$. Application of $30 \mathrm{kgN}$ was at par with $60 \& 90 \mathrm{~kg} \mathrm{~N}$ on root length and the similar result was obtained among $90 \& 120 \mathrm{~kg} \mathrm{~N}$. Similar results were obtained by Jilani et al. ${ }^{2}$ and Pervez et al. ${ }^{6}$ Increase in root length with higher level of $\mathrm{N}$ may be attributed to the increase in number of leaves. More the number of leaves more will be the assimilation of photosynthate by the process of photosynthesis which is further utilized for root cell differentiation and elongation.

\section{Root weight at 40 DAS}

The data revealed highly significant effect of $\mathrm{N}$ doses on root weight. Application of $150 \mathrm{~kg} \mathrm{~N}$ shows higher root weight (46.63g) which was significantly different with rest of the treatment. Under control treatment less root weight was obtained which was at par with $30 \mathrm{~kg} \mathrm{~N}$ and was significantly different with other $\mathrm{N}$ doses. The effect of $30 \& 60 \mathrm{~kg} \mathrm{~N}$ was found similar on root weight. Similar results were obtained by Patil et al. ${ }^{6}$ and Jilani et al. ${ }^{2}$ The increase in root weight with the increase in level of nitrogen is also due to the increased accumulation of photosynthate (carbohydrate and protein).

\section{Root weight at 50 DAS}

The mean value of root weight in table 2 shows highly significant effect of N. Application of $150 \mathrm{~kg} \mathrm{~N}$ has significantly higher root 
weight than other treatment and was at par with $120 \mathrm{~kg} \mathrm{~N}$. application of $30 \& 60 \mathrm{~kg} \mathrm{~N}$ shows similar effect on root weight meanwhile under control treatment root weight was significantly lower as compared to the other treatments. Similar results were obtained by Patil et al. ${ }^{6}$ and Jilani et al. ${ }^{2}$

\section{Conclusion}

From the above result and discussion we can conclude that higher level of nitrogen is required for attaining the optimum growth and yield of radish. Higher doses of N $120-150 \mathrm{~kg} /$ ha play significant effect on the growth and yield attributes. ${ }^{7}$

\section{Acknowledgment}

Foremost I would like to express my sincere gratitude to our teacher Mr. Amit khanal for his continuous support, his expertise and guidelines. Secondly, I would like to thanks to my colleagues Abishek, Amit, Sakar, Sharmila, Suruchi, Santosh, subash for their efforts on data recording in my absence and special thanks to Biwek for his guidance during data analysis. Last but not the least I would like to thanks all those who directly or indirectly helped me during my research.

\section{Conflicts of interest}

Authors declare that there is no conflict of interest.

\section{References}

1. Chapagain TR, S Piya NK, Dangal JL, et al. Comparison of commercial and local varieties of radish at different levels of manures and fertilizers. Nepal Journal of Science and Technology. 2010;11:51-56.

2. Jilani MS, T Burki, K Hussain. Effect of nitrogen on growth and yield of radish. Journal of Agricultural Research. 2010;48(2):219-225.

3. MOAD. Statistical information on nepalese agriculture. agriculture information and communication centre (AICC). 2013/14.

4. Baloch PA, Uddin R, Nizamani FK, et al. Effect of Nitrogen, Phosphorus and Potassium fertilizers on growth and yield characteristics of radish (Raphinus sativus L.). American-Eurasian J Agric and Environ Sci. 2014.14(6):565-569.

5. Pervez MA, CM Ayub, Basharat AS, et al. Effect of Nitrogen levels and spacing on growth and yield of Radish (Raphanus sativus L.). International Journal of Agriculture and Biology. 2004;6(3).

6. Patil HB, AA Patil, Hulamani NC. Effect of Nitrogen ,Phosphorus, Potassium and method of their application on growth and yield of Raddish (Raphanus sativus, cv Japanese White, Department of horticulture dharwad 580005). 1983.

7. MOAD. Krishi Diary, Agriculture information and communication centre (AICC). 2014/15. 